\title{
Debt Relief and Adjustment Effort in a Multi-Period Model
}

\author{
Sven Tengstam \\ Department of Economics, Göteborg University, Box 640, SE 40530 Göteborg, Sweden, Tel.: \\ +46-31-7731000,Fax:+46-31-7731326,E-mail: sven.tengstam@economics.gu.se
}

\begin{abstract}
This paper shows that if the period following the granting of debt relief is taken into account, debt relief increases adjustment effort (investment), irrespective of whether there is an initial debt overhang or not.
\end{abstract}

Keywords: HIPC; Debt relief; Debt overhang; Investment; Incentives

JEL classification: F34; H63; O11; O16

\section{Introduction}

What is the relation between external debt relief and adjustment effort or investment? Much of the literature seems to agree on two conclusions. First, debt relief can increase 
investment if initially there is a debt overhang. There are several reasons for this, although the one emphasized by many authors is that investment depends on expected tax rates which, in turn, depend on the face value of the debt (Helpman, 1989). A debt overhang means that the probability of full repayment of the debt is less than unity, so while expected debt repayments may increase following a debt reduction, the face value falls. Hence - and this is particularly valid for debt owed to commercial banks-debt relief may be in the interest of the debtor as well as the creditor (see Sachs, 1989, for the original argument).

The second conclusion is that one reason why governments engage in adjustment is because of the existence of a large external debt. To facilitate repayment, governments try to increase growth by resorting to measures such as liberalization, stimulation of the tradable sectors and fighting corruption. In the absence of a debt overhang, debt relief decreases the pressure to adjust and thus represents a disincentive to invest (Corden, 1989; see also Callier, 1989, for an extension). Based on these two conclusions it can be argued that debt relief only promotes investment in the presence of a debt overhang. This argument is used in the HIPC debate today (e.g., Arslanalp and Henry, 2004, and IMF and IDA, 2004).

The purpose of this paper is to argue that the second conclusion is valid only under rather restrictive assumptions. In particular, we show that if the situation after the actual granting of debt relief is taken into account, total adjustment effort increases irrespective of whether there is an initial debt overhang or not-a conclusion that runs contrary to much of the literature. 


\section{The Model}

Following Corden (1989), which is very similar to Sachs (1989), ${ }^{1}$ we treat adjustment effort and investment as equivalent, and assume the existence of a government that attempts to maximize an intertemporal utility function with present and future national consumption as arguments. Consumption in each period is normal. Part of each period's output, a function of the size of the capital stock, is consumed and the reminder is added to next period's capital stock. We are now at the end of period 1. At some time in the past, the government incurred a debt which is supposed to be serviced (or repaid) in period 3. Period 2, then, may be interpreted as a grace period. There is no debt overhang, i.e., the government is able and willing to service or repay the debt. The issue in Corden's three-period model is the effect of debt relief on the pattern and volume of consumption, and hence on investment. At the end of period 1, the government decides on a consumption plan $\mathbf{C}=\left\{C_{2}, C_{3}\right\}$ that maximizes discounted utility. Denoting with an asterisk variables when debt relief is given, the issue is whether and how $\mathbf{C}^{*}=\left\{C_{2}^{*}, C_{3}^{*}\right\}$ differs from $\mathbf{C}=\left\{C_{2}, C_{3}\right\}$. It is quite clear that $C_{2}^{*}>C_{2}$ and consequently that $S_{2}^{*}<S_{2}$, where $S$ denotes savings, since income in period 2 has not changed, but debt relief is granted in period 3, and period 2 consumption is a normal good. Since savings in a given period is identically equal to investment, or $S_{2}=I_{2}$, debt relief reduces the pressure to adjust:

\footnotetext{
${ }^{1}$ Sachs (1989) assumes the existence of a one period utility function which is additive and strictly concave and a production function which is concave, and hence that consumption in all periods are normal, and his model turns out to be a special case of the more general Corden (1989).
} 
“...debt service obligations in the future would increase investment now, and this can be interpreted to mean that current 'adjustment effort' is increased... It follows that debt relief would reduce investment and adjustment effort... This is the disincentive effect of debt relief." (Corden, 1989: 245)

While the Corden analysis is correct, it ignores some important aspects of debt relief. For one thing, it is quite possible that the investment effect in the relief period is different from that in the pre-relief period, so the net result need not be the one found by Corden.

To explore that possibility we extend the analysis by incorporating one additional period, period 4, which follows after the granting of debt relief. Thereby we can capture the behavior of agents in the period of the actual granting of relief. We now allow for savings in period 3 (but period 4 output will be consumed in its entirety). Writing $Y$ for output and $R$ for debt repayment, we have in the absence of debt relief that $C_{2}=Y_{2}-S_{2}$, $C_{3}=Y_{3}-S_{3}-R$, and $C_{4}=Y_{4}$. As before, relief is announced at the end of period 1 and granted in period 3. The government, at the end of period 1, decides on a consumption plan $\mathbf{C}=\left\{C_{2}, C_{3}, C_{4}\right\}$ that maximizes discounted utility. Similar to the reasoning above, the issue is whether and how $\mathbf{C}^{*}=\left\{C_{2}^{*}, C_{3}^{*}, C_{4}^{*}\right\}$ differs from $\mathbf{C}=\left\{C_{2}, C_{3}, C_{4}\right\}$. 


\section{Result}

As in the Corden analysis, $C_{2}^{*}>C_{2}$ because income has increased and period 2 consumption is a normal good, and therefore $S_{2}^{*}<S_{2}$ and $I_{2}^{*}<I_{2}$. However, if the behavior of agents in the period of the actual granting of relief is taken into consideration, the initial fall in investment observed by Corden might be counteracted by a subsequent increase in investment. Is it possible to say anything about the relative size of these two investment effects: what is the net effect of debt relief?

As it turns out, the net effect is that total investment unambiguously increases as a result of debt relief. The reason is simple: period 4 consumption is higher if debt relief is granted, since period 4 consumption is also a normal good. Consequently, period 4 output is higher. Since output depends on the size of the capital stock, the capital stock in period 4 is higher if debt relief is given. Since we start at the end of period 1 with a capital stock of a given size, the difference in period 4 consumption reflects differences in investment in periods 2 and 3. Hence, since $Y_{4}^{*}>Y_{4}$ we know that $\left(I_{2}^{*}+I_{3}^{*}\right)>\left(I_{2}+I_{3}\right)$. We have now shown that the investment effect in the relief period is stronger than the investment effect in the pre-relief period, and the net effect is the opposite of the one found by Corden. It is easy to show that adding even more time periods to our model does not change this result. ${ }^{2}$ Our conclusion is empirically supported by Cohen (1993) who investigates the

\footnotetext{
${ }^{2}$ Allowing for $n$ time periods and savings in all periods except the last, we get that $C_{4}, C_{5}, \ldots, C_{n}$ are all higher if debt relief is granted, since they are all normal. This requires entering period 4 in a better position, i.e. that the capital stock in period 4 is higher if debt relief is given. Hence, we know that
} 
impact of debt service on investment for 81 developing countries 1982-87. His analysis takes the behavior of agents in the period of the actual debt service into account. He finds a negative correlation, as we predict, irrespective of whether there is an initial debt overhang or not. ${ }^{3}$

\section{Conclusion}

While the analysis by Corden (1989) and others is correct insofar as the behavior of investment prior to the actual granting of debt relief is concerned, an important point is missed when the period immediately following debt relief is ignored. Since the relief period increase in investment is higher than the pre-relief decrease, the net effect of debt relief in an economy with no initial debt overhang is to increase, not decrease, total investment. Adding even more time periods to our model does not change this result. The time path of investment may change as a result of relief (specifically, investment are delayed), but the volume increases. Hence, debt relief stimulates adjustment, even in the absence of a debt overhang. Our analysis shows that the worries aired by Corden (1989: 251) regarding the possibility of debt relief being either too generous, or being given

$\left(I_{2}^{*}+I_{3}^{*}\right)>\left(I_{2}+I_{3}\right)$. The same kind of reasoning tells us that $\left(I_{2}^{*}+\ldots+I_{t}^{*}\right)>\left(I_{2}+\ldots+I_{t}\right)$ for any $2<t<n$ since $C_{t+1}, \ldots, C_{n}$ are all normal.

${ }^{3}$ He uses actual debt service instead of debt stock in his analysis, but we are primary interested in his results for the case with no debt overhang, and the two measurements are close in this case. Hofman and Reisen (1990) get similar results. 
when no debt overhang actually exists, and that this might reduce the economy's adjustment efforts, only is relevant if one ignores the behavior of agents in the period of the actual granting of relief.

\section{Acknowledgements}

First special thanks to Anders Danielson. I also thank Arne Bigsten and Gustav Hansson for comments, and Rick Wicks for editorial suggestions. I am of course solely responsible for any errors.

\section{References}

Arslanalp, S. and P. B. Henry, 2004, Helping the Poor to Help Themselves: Debt Relief or Aid, NBER Working Paper Series 10230

Callier, P., 1989, Debt Relief and Adjustment Incentives in a Financially Open Economy, IMF Staff Papers 36:2, 514-522

Cohen, D., 1993, Low Investment and Large LDC Debt in the 1980s, American Economic Review 83, 437-49

Corden, W. M., 1989, Debt Relief and Adjustment Incentives, in: J.A. Frenkel, M.P. Dooley and P. Wickham, eds., Analytical Issues in Debt (IMF, Whashington DC) 242-57

Helpman, E., 1989, Voluntary Debt Reductions. Incentives and Welfare, IMF Staff Papers 36:3, 580-611 
Hofman, B. and H. Reisen, 1990, Debt Overhang, Liquidity Constraints and Adjustment Incentives, OECD Development Centre Working paper 32

IMF and IDA, 2004, Debt Sustainability in Low-Income Countries - Proposal for an Operational Framework and Policy Implications

(http://siteresources.worldbank.org/INTDEBTDEPT/PolicyPapers/20270815/debtSustcompletepaper.pdf)

Sachs, J., 1989, The Debt Overhang of Developing Countries, in: G. Calvo, R. Fidlay, P. Kouri and J. B. de Macedo, eds., Debt, Stabilization and Development. Essays in Honor of Carlos DìazAlejandro (Blackwell, London) 